Max-Planck-Institut für demografische Forschung

Max Planck Institute for Demographic Research

Konrad-Zuse-Strasse 1 - D-18057 Rostock · GERMANY

Tel +49 (0) 3812081 - 0; Fax +49 (0) 3812081 - 202;

http://www.demogr.mpg.de

MPIDR WORKING PAPER WP 2005-013

MAY 2005

Gender Equality and Fertility in

Sweden: A Study on the Impact of the

Father's Uptake of Parental Leave on

Continued Childbearing

Ann-Zofie Duvander

Gunnar Andersson (andersson@ demogr.mpg.de)

This working paper has been approved for release by: Andres Vikat (vikat@demogr.mpg.de)

Deputy Head of the Laboratory of Contemporary European Fertility and Family Dynamics.

(C) Copyright is held by the authors.

Working papers of the Max Planck Institute for Demographic Research receive only limited review. Views or opinions expressed in working papers are attributable to the authors and do not necessarily reflect those of the Institute. 


\title{
Gender Equality and Fertility in Sweden: A Study on the Impact of the Father's Uptake of Parental Leave on Continued Childbearing
}

Ann-Zofie Duvander ${ }^{1}$ and Gunnar Andersson ${ }^{2}$

April 26, 2005

\begin{abstract}
In Sweden, the birth of a child induces the right to more than one year of paid parental leave that can be shared between the parents. This paper examines the relationship between the father's and the mother's respective use of such leave and the continued childbearing of a couple. Our investigation is based on longitudinal information on registered parental-leave use and childbearing of all intact unions in Sweden during 1988-99. We analyze our data by means of event-history analysis. We expect an extended paternal involvement in childrearing to be positively associated with continued childbearing since it makes family building more compatible with the mother's labor-force participation. In addition, such commitment to childrearing from the father's side is likely to signal a higher interest of his for continued family building. Around 85 percent of fathers take some leave but in most cases episodes are brief. We find a positive effect of a father's moderately long leave on a couple's second- and third-birth propensity, but no such effect of a very long paternal leave.
\end{abstract}

\footnotetext{
${ }^{1}$ Swedish Social Insurance Agency, Department of Research, Analysis and Statistics, Stockholm, Sweden.

${ }^{2}$ Max Planck Institute for Demographic Research, Rostock, Germany.
} 


\section{Introduction}

The main goal of Swedish family policy has been to support the reconciliation of active labor-force participation and family life of women and men (SOU, 1972). Public policies have been seen as an instrument in promoting gender equality both at the household level and in the labor market. A scheme of paid parental leave, which can be shared between parents, is a crucial component of these policies. The Swedish parental-leave system affects gendered behavior in two ways. First, it enhances the reconciliation of work and family life for women as its income-replacement character provides incentives to get established in the labour market before considering childbearing. It also allows women to keep a foothold in the labour market while taking care of the new-born child so that they can continue with labour-market work after the leave. Secondly, the parental-leave system encourages fathers to take parental leave, mainly through the months that are reserved for father's use. In this respect, Sweden is the only country in the EU which really can be considered as developing a system with the potential of altering gendered behavior in breadwinning and child care (Haas and Hwang, 1999; Haas, 2003). While the first impact of the parental-leave system has been quite successful, the second goal is still to be fulfilled. In comparison to men in other countries, Swedish men take parental leave relatively frequently (Kamerman, 2000), but they have certainly not entered the realm of household activities to the extent as women have entered the labor market. Fathers use only a fraction, still, of the total leave periods covered by the parental-leave insurance system (Sundström and Duvander, 2002). In response to the slow increase in fathers' uptake of parental leave, Swedish authorities have tried to promote a faster change in behavior. An increased paternal involvement in childrearing has been emphasized not only as a means to promote gender equality at the couple level but also to strengthen the emotional bonds between fathers and their children (Rostgaard, 2002). In our study, we ask whether a more active paternal involvement in terms of parental leave also can be related to a couple's subsequent childbearing behavior. Such involvement may enhance the compatibility between childrearing and labor-force participation of the mother and thereby make it easier for her to have another child. It signals the father's commitment to childrearing and possibly also to continued family building. In short, we wonder whether a higher degree of gender equality at the individual level, as 
measured by a more gender equal division of the parental leave, can be connected with higher fertility.

Swedish family policy has no explicit pronatalist goal, but often contains an assumption that gender equality indeed has a positive effect on fertility. The policy is otherwise formulated as a welfare issue, with the purpose of enabling couples to have the number of children they actually want to have (Ministry of Health and Social Affairs, 2001; Andersson, 2005). A positive impact of gender equality on fertility is nowadays often assumed in family-demographic research (e.g., Bernhard, 1993; Joshi, 1998; MacDonald, 2000a,b). In this respect, fathers' uptake of parental leave reflects one important aspect of gender equality at the couple level.

Our study thus deals with the issue of whether public policies can have an impact on childbearing behavior. Previous studies of possible relationships between family policy and fertility in Scandinavia have frequently focused on period effects on childbearing dynamics. Family policy is then treated as an aggregate-level factor and attention is given to noticeable changes in fertility after the implementation of some changes in that policy (for examples, see J. Hoem, 1990, 1993; Sundström and Stafford, 1992; Oláh, 2003; Andersson, 2004a; Rönsen, 2004). More rarely has the effect of the variation in individual use of a policy been studied (two important exceptions are given by Oláh, 2001, 2003). In our study, we use individual-level data on recipience of parental-leave benefits and subsequent childbearing of Swedish couples with one or two common children in order to estimate the possible effect of the uptake of parental leave on continued childbearing. The advantage of such a procedure is that it introduces some policy variation between individuals in the population, which better allows us to detect any effects of the particular policy on childbearing behavior.

Our paper begins with an overview of the Swedish parental-leave system and of fertility developments in Sweden. It is followed by a discussion of the possible connection between gender equality and childbearing. We then describe our data before turning to the results and our concluding discussion. 


\section{The Swedish parental-leave program}

The Swedish parental-leave program was introduced in 1974. It then gave the right to six months of paid leave from work after the birth of a child. Sweden was the first country in the world to introduce a gender neutral parental-leave scheme (for an international overview of parental-leave policies and their consequences, see Moss and Deven, 1999; Kamerman, 2000; Ferrarini, 2003). Employed mothers and fathers were granted an income replacement of 90 percent of their previous earnings up to a relatively high ceiling. Parents who have had no earnings prior to the use of the leave receive only a low flat rate. During the 1990s, this rate was equivalent to 6 Euro per day. All parents permanently residing in Sweden are entitled to parental leave. Such leave can be used in various ways: full-time, half-time, or quarter-time by either of the parents until the child turns eight. Benefits are paid out of the general tax system with no direct cost to employers. The parental-leave policy also comprises benefits for care of sick children to be used when parents have resumed labor-market activity. In 1980, ten additional so called "daddy days" to be used exclusively by the father in connection with childbirth were introduced.

The entitlement period was stepwise prolonged during the 1970s and 1980s. In 1989 it was extended to 15 months of which three months were paid at a low flat rate. Originally parents could split the leave between them as they preferred. Since 1995 one month of the leave is reserved for each parent, which popularly has been labeled as the introduction of a "daddy month". The intention was to increase fathers' use of parental leave. In 2002 a second month reserved for each parent was introduced as the leave was prolonged to 16 months. In 1995, 1996 and 1997 the income-replacement level was stepwise reduced to 75 percent, as public finances were strained, but was raised again to the present level of 80 percent from 1998. However, since the ceiling of the income-replacement level has not followed the income development, today a larger minority of parents are replaced at a lower level than the stipulated 80 percent. This applies especially to fathers who more often than mothers have earnings above the ceiling. In the early 1990s, around a tenth of fathers earned more than that level, which at present amounts to around 32,000 Euro on an annual basis (counted as earnings before tax but after social-security contributions). 
In sum, the Swedish parental-leave system is very generous in terms of income replacement, length, and flexibility (it can, for example, be prolonged by accepting a lower replacement level during a longer time), but fathers still use only a fraction of total leave (Sundström and Duvander, 2002). Table 1 demonstrates that the fathers' share of all benefit days has increased from only a half percent in 1974 when the policy was introduced to 12 percent of leave days 25 years later. After 1995, when the daddy month was introduced, the fraction of male leave users increased, but fathers on leave then took fewer days on average. This may be due to an influx of less motivated fathers, who used a few benefit days which would otherwise have been forfeited (Sundström and Duvander, 2002).

Economic characteristics are important determinants of Swedish fathers' use of parental leave. Both mother's and father's earnings have a positive impact on father's uptake; father's earnings have the strongest one (Sundström and Duvander, 2002; Nyman and Pettersson, 2002). However, father's uptake does not seem to increase with earnings above the ceiling of the income replacement, which could be interpreted as sensitivity to the cost of parental leave (Sundström and Duvander, 2002). Furthermore, fathers with longer education, employed in the public sector, and with partners with longer education take more leave than other fathers (Näsman, 1992; Haas, 1992; Sundström and Duvander, 2002; Nyman and Pettersson, 2002; Bygren and Duvander, 2004).

The huge impact of the level of earned income before childbirth on the benefit level during parental leave is a strong incentive to establish oneself in the labor market before considering becoming a parent. Indeed, the earned income is positively related to Swedish women's entry into motherhood (Hoem, 2000; Andersson, 2000; Duvander and Olsson, 2001). The same holds when entry into fatherhood is studied (Duvander and Olsson, 2001). In Sweden, labor-force participation of women at childbearing ages is high and almost parallel to that of men (Bygren, Gähler and Nermo, 2004).

\section{Fertility developments in Sweden}

During recent decades, Swedish fertility has evolved in a roller-coaster fashion (Hoem and Hoem, 1996) being positively related to the business cycle (Andersson, 2000). 
After an increase in fertility during the economic boom by the end of the 1980s and early 1990s, Sweden experienced a sharp decline in fertility during the 1990s. In 1990, the total fertility (TFR) of Sweden was 2.1 and among the highest in Europe. It subsequently fell to an unprecedented low of 1.5 in 1997-99. Subsequently, fertility has started to increase again (Andersson, 2004b). In 2004, the TFR of Sweden was close to 1.8 , which is similar to that of the other Nordic countries.

The mid-1990s was a period of economic hardship and labor-force participation of both women and men dropped. Many young women and men stayed longer in education when unemployment increased. The weaker attachment of young adults to the labor market was one of the reasons why fertility decreased during that period (Hoem, 2000; Andersson, 2000). The fertility decline was mainly due to young women postponing becoming a mother and two-child parents deciding not to have a third child. First births of women above 30 and second births were less affected. It has been suggested that the overall economic climate of the 1990s had a further role to play in the fertility decline than that given merely by the negative changes in individual labor-market attachment of young Swedes. Hoem (2000) found that the unemployment level in the local municipality mattered for women's first-birth patterns also when the individual labor-market status was considered. Cut-backs in family policies, like the mentioned reductions in income-replacement levels during parental leave, may also have affected fertility adversely. A reversal of such policy changes as the economy improved again by the turn of the century is likely to be positively related to the most recent increases in fertility.

\section{The possibility of a connection between the father's use of parental leave and continued childbearing}

A positive correlation between gender equality in the home and fertility is often suggested (e.g., Bernhard, 1993; Joshi, 1998; McDonald, 2000a,b) and sometimes even found in empirical studies based on individual-level data (for supportive evidence see, e.g., Buber, 2002; Mencarini and Tanturri, 2004). In our case, the sharing of parental leave between parents can be considered one measure of such equality. A finding in a study by Oláh (2003) indeed suggests that there was a positive 
impact of the father's uptake of parental leave on second births in Swedish couples during the 1970 s to 1980 s.

The major argument put forward for why gender equality would increase fertility is that a more equal division of labor in the household would ease women's work burden at home and thus enhance the degree of compatibility between childrearing and their labor-force participation. Such compatibility makes it easier to realize childbearing plans. In the case of parental leave of the father, it can, for example, facilitate a faster return to work of the mother. More crucial might be that a shared parental leave indicates a shared responsibility for childcare during the child's first year(s), and that it signals the father's commitment to share the care of children. The sharing of childcare in the child's early life is important, as patterns and divisions of such care are unlikely to change when the child grows older (Hwang and Lamb, 1997). A higher degree of gender equality might also affect fertility positively, in a more indirect way, if it affects women's well-being (Blair, 1993; Glass and Fujimuto, 1994) and the marital stability (Oláh, 2001) positively. Women in gender equal relationships may be more prone to continue childbearing in their present relationship.

It is equally important to consider the role of the father's desire for more children as both parents' childbearing plans are decisive for realized continued childbearing (Thomson, 1997; Thomson and Hoem, 1998). In this respect, a more gender equal division of parental leave is likely to be positively related also to the father's desire for more children. Kaufman (2000) finds that in the U.S., men with egalitarian attitudes are more likely to intend to have a child than other men. Bulanda (2004) demonstrates how egalitarian U.S. fathers are also more likely than traditional fathers to be involved with their children, and Hyde et al. (1993) show that they take relatively longer parental leave than other $\operatorname{men}^{3}$. In other words, a selection of men with preferences for children are likely to use a larger share of the parental leave and be more likely to continue childbearing; A father's uptake of parental leave signals an interest in children and childrearing, which as well is likely to be positively related to his childbearing intentions.

The actual experience of parental leave can both be negatively and positively related to the desire for more children. Men who share the leave may gain further

\footnotetext{
${ }^{3}$ In the U.S., periods of parental leave are very brief and often unpaid. For an update of recent developments, see Han and Waldfogel (2003).
} 
interest in children so that their desire for more children is strengthened. On the other hand, the work burden of childrearing may impede their desire for further children. The same holds with respect to the mother's experience of parental leave and her childbearing desires. When studying the relationship between the division of parental leave and the continued childbearing of a couple we also need to consider that a father's unusually large uptake of parental leave may mirror the mother's reduced interest in childrearing and future children, and vice versa. A very large uptake of parental leave, especially of the father, might also be due to a situation where the other parent is not entitled to a proper parental-leave benefit.

In a discussion of the impact of gender equality on childbearing we want to underline that only an equal - or close to equal - sharing of the parental leave indicates true gender equality. As long as the father's share of the parental leave is as small as it normally is today, it cannot really be seen as a reflection of gender equality in the family, nor in the labor market. Fathers' uptake of parental leave is important rather in the way it signals (i) a commitment to share the duties of childrearing with the mother, and (ii) an interest in children and the father-child relation as such.

Finally, our study will provide complementary insight into how mother's patterns of parental-leave use are related to a couple's continued childbearing. Practically all women in Sweden take extensive parental leave and the impact of their leave use on childbearing is likely to have other implications than that of men. For example, an unusually short uptake of parental leave on behalf of the mother might either indicate a quick return to the labor market due to her strong career orientation or reflect a situation where she is not entitled to an appropriate parental-leave benefit, given her prior weak attachment to the labor market.

\section{Data and method}

Our data are derived from Swedish population registers and cover the period 1988-99. They comprise demographic information on all coresiding couples with one or two common children who ever lived in Sweden during that period. The demographic data have been merged with information on registered earned income of these parents stemming from Swedish tax registers. Information on educational attainment has been added from other administrative registers. The data cover all couples where both 
partners are Swedish-born and where the couple's first common child also is the first child of the mother. Observations are censored when parents separate. The data on earned income is given on a yearly basis and include income replacements during periods of sickness and parental leave. (Parental-leave benefits are specified separately as well.) As the information is yearly, we are not able to sort out spells of parental leave and labor-market work within a given year. We use the information on paid parental-leave benefits during the period following childbirth as a determinant of the propensity to have another child during subsequent years.

As the information on income is given on a yearly basis and we want to follow parents' uptake of parental leave immediately after childbirth, we have restricted our data set to couples with a child born in January. Our data comprise 34,000 one-child couples and 27,000 two-child couples in 1988-99. We study the amount of parentalleave benefit paid to fathers and mothers of such children during the first two years following childbirth and relate these amounts to the earnings of the same parents during the same period. This gives the fraction of earnings that comes from the income replacement of the parental-leave system. We choose a period of two years after childbirth so that most parents are able to finish their parental leave within that period. Fathers who participate more actively in the parental-leave program often take most of their leave towards the end of the couple's parental-leave period, which is likely to occur more than one year after childbirth. Our design means that couples who have a birth already within this two-year period are excluded from our study. This amounts to around a fifth of the combined number of second and third births.

In our analyses of the impact of parents' uptake of parental leave on continued childbearing, we relate subsequent registered births to the corresponding exposure times of risk of having another child. This amounts to an event-history analysis of childbearing behavior where we control for a number of demographic and socioeconomic factors. We estimate models for second and third births separately since we know that fertility patterns differ by parity. Almost all one-child parents proceed to have a second birth, which means that models for that parity progression mainly cover the timing of such births (see Oláh, 2003, for further analyses of second births in Sweden). Around half of two-child couples proceed to have a third child which means that the latter models also distinguish between those who eventually have such a child and those who do not (see Berinde, 1999; Corman, 2001 on third births in Sweden). 
Our demographic control variables include age of woman in three-year age groups from 19-21 to 40-42 years, age difference between parents, and time since previous birth, that is, age of the youngest child. We also control for calendar-year period with two-year groups from 1988-89 to 1998-99. The estimates of the control variables are not presented in this paper but are available in Duvander and Andersson (2004). As both continued childbearing and parents' use of parental leave are influenced by human capital and economic resources we present models with and without control for the earned income of the couple and for parents' educational attainment. The couple income, recalculated at the price level of 1995, is categorized into low level of annual earnings (0-250,000 Swedish kronor $\left.{ }^{4}\right)$, medium earnings (250-400,000 Swedish kronor), high earnings (400-550,000 Swedish kronor) and top earnings (more than 550,000 Swedish kronor). We include the educational level of both father and mother, for which information is updated every year and categorized into primary, secondary, and tertiary education.

Our prime variables are father's and mother's uptake of parental-leave benefits. As patterns in parental-leave use differ between men and women, we have categorized the variables for fathers and mothers differently. Father's use of parental leave is categorized into a) no leave benefit, b) leave benefit amounting to up to 3 percent of the earned income during the two years following childbirth, c) leave benefit equivalent to 3-10 percent of the income, d) leave benefit equivalent to 11-25 percent of the earned income, and e) benefit equivalent to more than a quarter of that income. A situation where the father has received less than 3 percent of his earned income from the parental-leave insurance means that he probably only has used the so called "daddy days". These days are taken in immediate connection to the birth and do not imply a situation where the father is at home with the child on his own. More extensive uptake of parental leave is more likely to refer to situations where the father stays at home as the prime caregiver of the child.

Mother's use of parental leave is categorized into a) leave benefit equivalent to less than 25 percent of the earned income during the two years following childbirth, b) leave benefit equivalent to $25-50$ percent of that income, c) leave benefit equivalent to 51-75 percent of the earned income, and d) more than 75 percent of the earned

\footnotetext{
${ }^{4}$ The value of one Swedish krona is approximately 11 Euro cents.
} 
income being an income replacement from the parental-leave system. The latter category is likely to reflect a situation where a mother hardly returned to work during the two-year period immediately following childbirth.

Table 2 gives the distributions of exposure time to the risk of a second and a third birth, respectively, over the various categories of father's and mother's uptake of parental leave, couple income, and educational attainment. Patterns are very similar for the two birth orders. Slightly more than a tenth of fathers used no leave at all. The largest categories are those of fathers who received less than 3 or 3-10 percent of their income from the parental-leave insurance. Only 3-4 percent of fathers fall into the category where more than a quarter of their income came from such benefits. The category of mothers where less than a quarter of the earned income came from the parental-leave insurance is equally small. Only 4-5 percent of mothers fall into that category. The categories where up to half and up to three quarters of the income came from parental-leave benefits are the most common for mothers. The exposures corresponding to the highest dependence on the parental-leave insurance, where more than three quarters of earnings were of that character, comprise only 14-15 percent of Swedish mothers' after-birth periods.

\section{Results}

The results of our models are presented in Table 3. The models on second births (Table 3a) reveal a positive impact of father's uptake of parental leave on that parity progression. Couples where the father takes parental leave have considerably higher second-birth intensities than couples where the father takes no leave at all, and second-birth risks increase with an increasing level of paternal parental-leave use. However, this relationship only holds up to the small category of one-child couples where the father takes very extensive leave. Such couples rather have reduced secondbirth intensity. The basic relationship between father's parental-leave use and second birth is relatively unaffected by the control for our socio-economic variables.

The relationship between mother's parental-leave use and second births is also not so strongly affected by the controls for couple income and educational characteristics. Second-birth risks are highest for the most common categories of couples where the woman has got between one and three quarters of her earnings 
from the parental-leave system. Very low and very high levels of maternal uptake of leave are related to a reduced risk of second birth. It is thus the normative pattern of behavior that is related to the highest second-birth risk. The extreme users, be they men or women, have the lowest risks.

Second-birth risks are mainly indicative of the timing of births of that order. Third-birth risks are to a larger extent related also to the outcome in terms of children ever born. Table $3 \mathrm{~b}$ indicates that couples where the father has made a relatively large uptake of parental leave have the highest third-birth fertility. Such couples have about 10 percent higher third-birth fertility than other couples (Model 1b). However, in this case the relationship is strongly affected by the control for parents' educational characteristics and couple income. Educational groups with high third-birth risks, i.e., mothers and fathers with high educational level ${ }^{5}$, are over-represented in the group where fathers take extended leave. With the control for educational characteristics the positive effect of paternal leave use on third-birth risks vanishes (Model 3b). The control for couple income has the opposite effect and when both types of socioeconomic variables are included in the model we find a weak but still clearly positive impact of father's uptake of parental leave, except for the small category where he got more than a quarter of his income from the parental-leave system (Model 4b).

For third births, the impact of the mother's use of parental leave is quite the opposite of what we found for second births. There is a J-shaped pattern in the relationship between mother's leave use after the second birth and third-birth fertility. Couples where the mother got more than three quarters of her income from leave benefits have the far highest third-birth intensities; they are around a third higher than for other couples with two children. In many cases, such an extensive uptake is likely to reflect a situation where the mother never returned to the labor market as the couple was waiting for the arrival of a third child.

\footnotetext{
${ }^{5}$ In studies on educational gradients in second- and third-birth risks it is common to find positive effects of educational attainment like we find here. People have spent much energy explaining, or explaining away the positive pattern for women, which contradicts common theory about education and fertility. Among procedures applied are sophisticated uses of the covariate "age at first birth" (see in particular B. Hoem, 1996) and arguments involving differential childbearing selectivity at different educational attainments (see, e.g., Hoem, Prskawetz, and Neyer, 2001; Kravdal, 2001; Kreyenfeld, 2002).
} 


\section{Discussion}

The purpose of this study was to examine how paternal participation in the parental leave after the birth of a child is related to the subsequent fertility of Swedish couples. This amounts to the study of the impact of individual use of an important familypolicy component on individual fertility. More specifically, we consider a father's involvement in the parental leave as one crucial aspect of the degree of gender equality in the parental couple. We expect a higher degree of such equality to be positively correlated with couple fertility. Indeed, we find that father's uptake of parental leave is positively related to continued childbearing. Couples where the father took some leave have higher second- and third-birth propensities than couples where the father took no leave at all, and couples where the father took a leave corresponding to more than the one to two weeks of so called "daddy days" have higher fertility than couples where the father only took very brief leave. The positive relationship is broken however at the small group of couples where the father took really extensive leave.

When interpreting these results, we have to be aware that present levels of paternal parental-leave use in Sweden cannot really be taken as a reflection of true gender equality. Fathers take only a fraction still of all parental leave, and we regard the patterns we find as more indicative of positive effects of the father's commitment to share the responsibilities and joys of childrearing than of any true gender equity in the couple. In terms of policy effects, however, our results give some support for the possibility that active paternal involvement in a parental-leave scheme like that of Sweden can be positively related to individual fertility. Nevertheless, we need to be aware that the patterns we find cannot be taken as firm support for the existence of causal effects of parental-leave use on couple fertility. Selection effects are likely to be at play where fathers who are more inclined to have further children also is more likely to take parental leave and have a higher propensity to have a next child. Other underlying factors may affect both parental-leave use and continued childbearing. The possibility of such an impact of unobserved characteristics also holds for the negative effect we found of father's very extensive parental-leave use on couple childbearing. A further inspection reveals that couples where the father received an unusually large fraction of his income from the parental-leave system commonly are low-income earners. The low income of these couples might mask some further characteristics that 
are negative for continued childbearing, such as non-qualification of the mother for a proper parental-leave benefit or the drop-out of the father from labor-market activity ${ }^{6}$.

In our study, we could also demonstrate that one-child couples where the mother took an average amount of parental leave had the highest second-birth fertility. This is likely to indicate a connection between normative use of parental leave and the norm to have a second child. For two-child couples we rather found a polarization in the relationship between mother's use of parental leave and third-birth propensities. This supports the notion of differential pathways to a third child in Sweden, with higher third-birth fertility of mothers with strong as well as reduced attachment to the labor market (Berinde, 1999; Corman, 2001). The situation with an extended parental leave of the mother is likely to reflect a temporary withdrawal from labor-market activity in anticipation of a third child. Such pattern in behavior shows that third-birth fertility need not always be related to more egalitarian family dynamics.

To conclude, we found some evidence that increased paternal involvement in childrearing indeed is positively related to continued childbearing, but we are careful in not claiming that our findings necessarily reflect the causal impact of gender-equal behavior on couple fertility. In addition, to study the effect of true gender equality on couple fertility would require that it is much more common that fathers take extensive periods of parental leave than what it is today. A development towards a more symmetrical division of parental leave would also put some pressure on Swedish mothers to give up a larger fraction of this generous benefit. Nevertheless, Swedish fathers' share of parental-leave use is steadily increasing and it is plausible that further increases will be connected to a more gender equal and child friendly Swedish society.

\footnotetext{
${ }^{6}$ In general, childbearing of Swedish parents is more sensitive to weak labor-market attachment of the mother than to weak attachment of the father. Weak paternal labor-market performance can even be positively related to couple fertility (Duvander and Andersson, 2003; Andersson et al., 2005).
} 


\section{Acknowledgments}

We are grateful to Statistics Sweden for providing us with the demographic raw data, to Jonathan MacGill for assistance in organising the data, and to the Max Planck Institute for Demographic Research for providing its facilities to Ann-Zofie Duvander while we were working together on this project at the mentioned institute.

\section{References}

Andersson, G. 2000. The impact of labor-force participation on childbearing behavior: Pro-cyclical fertility in Sweden during the 1980s and the 1990s. European Journal of Population 16: 293-333.

Andersson, G. 2004a. Childbearing developments in Denmark, Norway, and Sweden from the 1970s to the 1990s: A comparison. Demographic Research Special Collection 3(7): 155-176. Available http://www.demographic-research.org.

Andersson, G. 2004b. Demographic trends in Sweden: An update of childbearing and nuptiality up to 2002. Demographic Research 11(4): 95-110. Available http://www.demographic-research.org/Volumes/Vol11/4.

Andersson, G. 2005. A study on policies and practices in selected countries that encourage childbirth: the case of Sweden. Contribution to the "Consultancy Study on Population Related Matters - A Study on Policies and Practices in Selected Countries that Encourage Childbirth" for the Government of Hong Kong Special Administrative Region. MPIDR Working Paper 2005-05. Rostock: Max Planck Institute for Demographic Research.

Andersson, G., A.-Z. Duvander and K. Hank. 2005. Erwerbsstatus und Familienentwicklung in Schweden aus paarbezogener Perspektive. In Männer - Das ,vernachlässigte' Geschlecht in der Familienforschung [Sonderheft 4 der Zeitschrift für Familienforschung], edited by A. Tölke and K. Hank, pp. 220-234. Wiesbaden: VS Verlag für Sozialwissenschaften.

Berinde, D. 1999. Pathways to a third child in Sweden. European Journal of Population 15: 349-378.

Bernhardt, E. 1993. Fertility and employment. European Sociological Review 9: 2542. 
Blair, S. L. 1993. Employment, family, and perceptions of marital quality among husbands and wives. Journal of Family Issues 14: 189-212.

Buber, I. 2002. The influence of the distribution of household and childrearing tasks between men and women on childbearing intentions in Austria. MPIDR Working Paper 2002-004. Rostock: Max Planck Institute for Demographic Research.

Bulanda, R. E. 2004. Paternal involvement with children: The influence of gender ideologies. Journal of Marriage and Family 66: 40-45.

Bygren, M. and A.-Z. Duvander. 2004. "Ingen annan på jobbet har ju varit pappaledig..." Papporna, deras arbetsplatser och deras pappaledighetsuttag. In Familj och arbete - Vardagsliv i förändring, edited by M. Bygren, M.Gähler and M. Nermo, pp 166-199. Stockholm: SNS Förlag.

Bygren, M., M. Gähler and M. Nermo. 2004. Familj och arbete - Vardagsliv i förändring. In Familj och arbete - Vardagsliv $i$ förändring, edited by M. Bygren, M.Gähler and M. Nermo, pp 11-55. Stockholm: SNS Förlag.

Corman, D. 2001. Success at Work and in Family Life: Studies in Selected Western Fertility and Family Dynamics. Demography Unit Dissertation Series 4. Stockholm: Stockholm University.

Duvander, A.-Z. and S. Olsson. 2001. När har vi råd att skaffa barn? RFV analyserar 2001: 8. Stockholm: National Social Insurance Board.

Duvander, A.-Z. and G. Andersson. 2003. När har vi råd att skaffa fler barn? En studie om hur inkomst påverkar fortsatt barnafödande. RFV analyserar 2003: 8. Stockholm: National Social Insurance Board.

Duvander, A.-Z. and G. Andersson. 2004. Leder delad föräldraledighet till fler barn? En studie om hur pappors och mammors föräldrapenninguttag påverkar benägenheten att skaffa ytterligare barn. RFV analyserar 2004: 15. Stockholm: National Social Insurance Board.

Ferrarini, T. 2003. Parental Leave Institutions in Eighteen Post-war Welfare States. Swedish Institute for Social Research, Dissertation Series. Stockholm: Stockholm University.

Glass, J. and T. Fujimoto. 1994. Housework, paid work, and depression among husbands and wives. Journal of Health and Social Behavior 35: 179-191.

Haas, L. 1992. Equal Parenthood and Social Policy: A Study of Parental Leave in Sweden. Albany: State University of New York Press. 
Haas, L. 2003. Parental leave and gender equality: Lessons from the European Union. Review of Policy Research 20: 89-114.

Haas, L. and P. Hwang. 1999. Parental leave in Sweden. In Parental Leave: Progress or Pitfall?, edited by P. Moss and F. Deven, pp 45-68. The Hague/Brussels: NIDI/CBGS Publications, Vol. 35.

Han, W.-J. and J. Waldfogel. 2003. Parental leave: The impact of recent legislation on parent's leave taking. Demography 40: 191-200.

Hoem, B. 1996. The social meaning of the age at second birth for third-birth fertility: A methodological note on the need to sometimes respecify an intermediate variable. Yearbook of Population Research in Finland 33, 333-339.

Hoem, B. 2000. Entry into motherhood in Sweden: the influence of economic factors on the rise and fall in fertility, 1986-1997. Demographic Research [Online] 2. Available http://www.demographic-research.org/Volumes/Vol2/4.

Hoem, B. and J. M. Hoem. 1996. Sweden's family policies and roller-coaster fertility. Jinko Mondai Kenkyu (Journal of Population Problems) 52: 1-22.

Hoem, J. M. 1990. Social policy and recent fertility change in Sweden. Population and Development Review 16: 735-748.

Hoem, J. M. 1993. Public policy as the fuel of fertility: effects of a policy reform on the pace of childbearing in Sweden in the 1980s. Acta Sociologica 36: 19-31.

Hoem, J. M., A. Prskawetz and G. Neyer. 2001. Autonomy or conservative adjustment? The effect of public policies and educational attainment on third births in Austria, 1975-96. Population Studies 55: 249-261.

Hwang, C-P. and M. E. Lamb. 1997. Father involvement in Sweden: A longitudinal study of its stability and correlates. International Journal of Behavioral Development 21: 621-632.

Hyde, J. S., M. Essex and F. Horton. 1993. Fathers and parental leave: Attitudes and experiences. Journal of Family Issues 14: 616-641.

Joshi, H. 1998. The opportunity costs of childbearing: More than mothers' business. Journal of Population Economics 11:161-183.

Kamerman, S. 2000. Parental leave policies: An essential ingredient in early childhood education and care policies. Social Policy Report 14: 3-15.

Kaufman, G. 2000. Do gender role attitudes matter? Family formation and dissolution among traditional and egalitarian men and women. Journal of Family Issues 21: 128-144. 
Kravdal, Ø. 2001. The high fertility of college educated women in Norway: An artefact of the separate modelling of each parity transition. Demographic Research 5: 187-216. Available http://www.demographicresearch.org/Volumes/Vol5/6.

Kreyenfeld, M. 2002. Time-squeeze, partner effect or self-selection? An investigation into the positive effect of women's education on second birth risks in West Germany. Demographic Research 7: 15-47. Available http://www.demographicresearch.org/Volumes/vol7/2.

McDonald, P. 2000a. Gender equity, social institutions and the future of fertility. Journal of Population Research 17: 1-16.

McDonald, P. 2000b. Gender equity in theories of fertility transition. Population and Development Review 26: 427-439.

Mencarini, L. and M. L. Tanturri. 2004. Time use, family role-set and childbearing among Italian working women. Genus LX (1): 111-137.

Ministry of Health and Social Affairs. 2001. Barnafödande $i$ fokus: Från befolkningspolitik till ett barnvänligt samhälle. Ministry Publications Series Ds 2001:57. Stockholm: Fritzes.

Moss, P. and F. Deven. 1999. Parental Leave: Progress or Pitfall? The Hague/Brussels: NIDI/CBGS Publications, Vol. 35.

Näsman, E. 1992. Parental leave in Sweden - a workplace issue? Stockholm Research Reports in Demography 73. Stockholm: Stockholm University.

Nyman, H. and J. Pettersson. 2002. Spelade pappamånaden någon roll? RFV analyserar 2002: 14. Stockholm: National Social Insurance Board.

Oláh, L. Sz. 2001. Gender and family stability: Dissolution of the first parental union in Sweden and Hungary. Demographic Research 4: 27-96. Available http://www.demographic-research.org/Volumes/Vol4/2/.

Oláh, L. Sz. 2003. Gendering fertility: Second births in Sweden and Hungary. Population Research and Policy Review 22: 171-200.

Rønsen, M. 2004. Fertility and family policy in Norway - A reflection on trends and possible connections. Demographic Research 10: 266-286. Available http://www.demographic-research.org/Volumes/Vo10/10/.

Rostgaard, T. 2002. Setting time aside for the father: Father's leave in Scandinavia. Community, Work \& Family 5: 343-364.

SOU. 1972. Familjestöd. SOU 1972: 34. Stockholm: Regeringskansliet. 
Sundström, M. and A.-Z. Duvander. 2002. Gender division of childcare and the sharing of parental leave among new parents in Sweden. European Sociological Review 18: 433-447.

Sundström, M. and F. Stafford. 1992. Female labour force participation, fertility and public policy in Sweden. European Journal of Population 8: 199-215.

Thomson, E. 1997. Couple childbearing desires, intentions, and births. Demography 34: 343-54.

Thomson, E. and J. M. Hoem. 1998. Couple childbearing plans and births in Sweden. Demography 35: 315-22. 
Table 1: Fathers' share of parental-leave use in Sweden, 1974-2004

\begin{tabular}{|c|c|c|c|}
\hline & $\begin{array}{c}\text { Fraction of benefit days } \\
\text { used by fathers } \\
\text { (percent) }\end{array}$ & $\begin{array}{c}\text { Fraction of men of } \\
\text { parental-leave users } \\
\text { (percent) }\end{array}$ & $\begin{array}{c}\text { Average number of } \\
\text { days used by fathers } \\
\text { who took leave in a year }\end{array}$ \\
\hline 1974 & 0.5 & 2.8 & 21 \\
\hline 1975 & 0.9 & 4.0 & 30 \\
\hline 1976 & 1.4 & 5.2 & 36 \\
\hline 1977 & 2.2 & 7.0 & 42 \\
\hline 1986 & 6.2 & 23.0 & 26 \\
\hline 1987 & 7.5 & 24.5 & 29 \\
\hline 1988 & 6.5 & 23.1 & 31 \\
\hline 1989 & 6.9 & 24.6 & 32 \\
\hline 1990 & 7.1 & 26.1 & 33 \\
\hline 1991 & 8.1 & 26.5 & 39 \\
\hline 1992 & 9.1 & 26.9 & 43 \\
\hline 1993 & 10.1 & 27.4 & 45 \\
\hline 1994 & 11.4 & 28.3 & 44 \\
\hline 1995 & 9.6 & 27.9 & 34 \\
\hline 1996 & 10.6 & 31.1 & 30 \\
\hline 1997 & 9.9 & 30.9 & 28 \\
\hline 1998 & 10.4 & 32.4 & 27 \\
\hline 1999 & 11.9 & 36.2 & 29 \\
\hline 2000 & 12.7 & 37.7 & 28 \\
\hline 2001 & 14.1 & 39.9 & 29 \\
\hline 2002 & 15.9 & 41.6 & 30 \\
\hline 2003 & 17.6 & 42.7 & 32 \\
\hline 2004 & 18.7 & 43.2 & 32 \\
\hline
\end{tabular}

Source: Calculations based on data from the National Social Insurance Agency. 
Table 2: Exposures of risk to a second and a third birth. Fractions of couple months for each variable (percent)

\begin{tabular}{lll}
\hline Variable & One-child parents & Two-child parents \\
\hline
\end{tabular}

Father's uptake of parental leave during the first/second child's first two years

No leave benefit

13.8

11.7

Less than $3 \%$ of earned income

38.6

39.6

$3-10 \%$ of earnings

31.0

33.2

$11-25 \%$ of earnings

12.7

12.6

More than $25 \%$ of earnings

3.9

2.9

Mother's uptake of parental leave during the first/second child's first two years

Less than $25 \%$ of earned income

5.0

3.9

$25-50 \%$ of earnings

40.1

40.3

$51-75 \%$ of earnings

40.7

40.8

More than $75 \%$ of earnings

14.1

15.0

Couple earnings

Low

24.2

Medium

55.4

63.7

High

16.4

13.2

Top

4.1

2.8

Woman's educational level

Primary

12.6

11.2

Secondary

59.9

58.5

Tertiary

27.5

30.3

Man's educational level

Primary

19.4

18.8

Secondary

55.5

52.8

Tertiary

25.1

28.3 
Table 3a: Relative risk of a second birth of Swedish couples with one common child, by parents' parental-leave use and their socio-economic characteristics. Standardised for age of mother, age difference between parents, time since first birth, and calendar year.

\begin{tabular}{|c|c|c|c|c|}
\hline Variable & Model 1a & Model 2a & Model 3a & Model 4a \\
\hline \multicolumn{5}{|l|}{$\begin{array}{l}\text { Father's uptake of parental leave } \\
\text { during first child's first two years }\end{array}$} \\
\hline No leave benefit & 1 & 1 & 1 & 1 \\
\hline Less than $3 \%$ of earned income & 1.16 & 1.13 & 1.16 & 1.13 \\
\hline $3-10 \%$ of earnings & 1.23 & 1.19 & 1.21 & 1.18 \\
\hline $11-25 \%$ of earnings & 1.26 & 1.23 & 1.21 & 1.17 \\
\hline More than $25 \%$ of earnings & 0.93 & 0.97 & 0.90 & 0.94 \\
\hline \multicolumn{5}{|l|}{$\begin{array}{l}\text { Mother's uptake of parental leave } \\
\text { during first child's first two years }\end{array}$} \\
\hline Less than $25 \%$ of earned income & 0.91 & 0.89 & 0.84 & 0.84 \\
\hline $25-50 \%$ of earnings & 1 & 1 & 1 & 1 \\
\hline $51-75 \%$ of earnings & 1.04 & 1.05 & 1.05 & 1.06 \\
\hline More than $75 \%$ of earnings & 0.93 & 0.96 & 0.93 & 0.96 \\
\hline \multicolumn{5}{|l|}{ Couple earnings } \\
\hline Low & & 0.84 & & 0.83 \\
\hline Medium & & 1 & & 1 \\
\hline High & & 1.08 & & 0.98 \\
\hline Top & & 1.26 & & 1.05 \\
\hline \multicolumn{5}{|l|}{ Woman's educational level } \\
\hline Primary & & & 0.75 & 0.75 \\
\hline Secondary & & & 1 & 1 \\
\hline Tertiary & & & 1.23 & 1.23 \\
\hline \multicolumn{5}{|l|}{ Man's educational level } \\
\hline Primary & & & 0.89 & 0.89 \\
\hline Secondary & & & 1 & 1 \\
\hline Tertiary & & & 1.20 & 1.18 \\
\hline
\end{tabular}

Note: Reference level of each variable given without decimals 
Table 3b: Relative risk of a third birth of Swedish couples with two common children, by parents' parental-leave use and their socio-economic characteristics. Standardised for age of mother, age difference between parents, time since second birth, and calendar year.

\begin{tabular}{|c|c|c|c|c|}
\hline Variable & Model 1b & Model 2b & Model 3b & Model 4b \\
\hline \multicolumn{5}{|l|}{$\begin{array}{l}\text { Father's uptake of parental leave } \\
\text { during second child's first two } \\
\text { years }\end{array}$} \\
\hline No leave benefit & 1 & 1 & 1 & 1 \\
\hline Less than $3 \%$ of earned income & 1.01 & 1.06 & 0.99 & 1.04 \\
\hline $3-10 \%$ of earnings & 1.04 & 1.10 & 1.00 & 1.07 \\
\hline $11-25 \%$ of earnings & 1.13 & 1.18 & 1.02 & 1.07 \\
\hline More than $25 \%$ of earnings & 1.11 & 1.10 & 1.00 & 0.99 \\
\hline \multicolumn{5}{|l|}{$\begin{array}{l}\text { Mother's uptake of parental leave } \\
\text { during second child's first two } \\
\text { years }\end{array}$} \\
\hline Less than $25 \%$ of earned income & 1.11 & 1.08 & 1.06 & 1.03 \\
\hline $25-50 \%$ of earnings & 1 & 1 & 1 & 1 \\
\hline $51-75 \%$ of earnings & 1.11 & 1.10 & 1.10 & 1.09 \\
\hline More than $75 \%$ of earnings & 1.39 & 1.33 & 1.42 & 1.34 \\
\hline \multicolumn{5}{|l|}{ Couple earnings } \\
\hline Low & & 1.24 & & 1.26 \\
\hline Medium & & 1 & & 1 \\
\hline High & & 1.10 & & 0.94 \\
\hline Top & & 1.42 & & 1.10 \\
\hline \multicolumn{5}{|l|}{ Woman's educational level } \\
\hline Primary & & & 0.86 & 0.85 \\
\hline Secondary & & & 1 & 1 \\
\hline Tertiary & & & 1.54 & 1.55 \\
\hline \multicolumn{5}{|l|}{ Man's educational level } \\
\hline Primary & & & 0.94 & 0.92 \\
\hline Secondary & & & 1 & 1 \\
\hline Tertiary & & & 1.22 & 1.22 \\
\hline
\end{tabular}

Note: Reference level of each variable given without decimals 